\title{
In A Perfect Storm
}

\section{An Interview with Simon Critchley on Political Disappointment and the Intellectual Left}

\author{
Hans Boas Dabelsteen \\ PhD Fellow, Department of Political Science, University of Copenhagen
}

As 2012 was drawing to a close, POLITIK had a Skype talk with New School philosopher Simon Critchley on his thoughts on "the intellectual Left“ of today, how it can be characterized and how Critchley understands his philosophy in that connection. Critchley's political work has been engaged with questions of ethics and commitment motivated by political disappointment. His ideas of an ethically committed political anarchism led him into heated discussions with Slavoj Žižek from the last half of the 2000's. Recently, he has been involved in the Occupy Wall Street movement.

Hans Boas Dabelsteen (HBD): Let us begin with a fairly broad question, which may set the tone for this conversation. It has often been pointed out that the intellectual left of today is like a toothless tiger: In spite of apparent impressive intellectual might, it has not been able to provide any political ammunition of actual leftish political action.

As such, the intellectual project of the left has been deemed impotent by some, lacking both a proper alternative to the prevailing political order and-perhaps most importantly - an idea of how to get there. At different occasions you analyzed and discussed several thinkers which by many have been defined as thinkers of the left: Jacques Derrida, Ernesto Laclau, Chantal Mouffe, Judith Butler, Slavoj Žižek, Michael Hardt, Alain Badiou and others. From your perspective: what is left of "the Left" today?

Simon Critchley (SC): A lot, although I question the assumption behind the question, talking about the intellectual left as being toothless. It depends on how you look at things. In relation to the generation of ' 68 , there was this idea of ,an intellectual left“ actually making a difference, and I suppose so. On the other hand, I'm not so persuaded by that, and I think there is a narrative, in particular a narrative of Marxism-Leninism, which I find rather ideological in a way.

For me, the intellectual Left, whatever that means, is not a toothless tiger. You can't point to a political transformation through concepts alone or through philosophy alone - I don't really believe in political philosophy in that way.

I think you have to be attentive to potentialities that are there on the ground and be more of an anthropologist than a philosopher. If you look at which potentialities there are on the ground, for the most part history has always been written by the people with guns and sticks and it will always remain that way. Because you got guns and sticks you can terrify people.

So the task of the Left is, as I understand it, not to issue proclamations of revolution. I don't really believe in revolution as a category. It is not one I find particularly helpful. However, we should be able to provide a set of concepts or even slogans that might make those potentialities more actual.

Also, I don't believe in the tigery image. This love affair the Left has had with machismo politics has found its farcical expression in the so-called return of communism, with Žižek and others, which I find to be kind of a joke. I just don't take it seriously. It is boys with videogames fantasizing about violence. But let us just put that to one side.

If we look at what has happened in the last couple of years, it seems to me that amazing things has happened. Those things are characterized by ambiguity, and it re- 
quires a broad historical view and some patience to grasp. There is a sense on the left of always wanting to shoot ourselves at the first opportunity, like: „Occupy failed“, or: "the Arab Spring failed", but for me it's the other way around. It took place, so how can we think about that something happened? And, if you will, the intellectual discipline of the Left needs to take a look at the longue durée, the broad historical sweep, and not become impatient with what's happening, melancholically declaring that nothing happened. Occupy is a good example: It happened and it continues to happen in interesting and unpredictable ways in places like New York.

$H B D$ : As a result, your reading of the situation is not that the intellectual Left is loosing its importance in the public conversation these years?

SC: Not really, and I don't really see that. In many ways it was much worse in the 1990's when people believed that a reformed version of liberal democracy was going to be our salvation. There was all this enthusiasm around democratic theory which I found to be much more depressing. I find the situation the last couple of years very interesting and all sort of figures have emerged.

I was at the University of Essex where I worked very close with Ernesto Laclau for many years, and I learned a lot about how to think about politics from him, which he really took from Gramsci. I think there are many things we can still learn from Gramsci, which implies a certain humility or modesty about what is politically possible.

Gramsci was writing in the context of the fascist takeover in Italy - the total failure of the Marxist project - and yet he produced a series of concepts, which are able to resist that situation. A central category here is the category, which he calls the organic intellectual. That interests me much more than the Leftist academic intellectual.

I'm a Leftist academic intellectual and there are plenty of those around. We have a certain function, but more important is the emerging of an organic intellectual that would be someone from an actual movement. Someone who can articulate at some higher level the nature of that movement. How that movement might become more coherent and more powerful.

One of the interesting things about Occupy as an example here is that it consists of many organic intellectuals. It really had no expectation of being involved in a political situation, and then found a voice. For me, that's what the intellectual Left is about. People who suddenly find themselves in a situation where they have a voice. The idea of there being a group of theorists who can produce a series of categories - that we can go to them for recipes for how we can produce revolutionary situations - I find a bit ludicrous and out-of-date. And if philosophers are doing that, they should stop.

We have to be more anthropological and historical and we have to be more local. Politics for me is an essentially local activity, and one have to have a very detailed anthropological knowledge about what is going on and what is possible in a locality. And again, Gramsci was very good at that. He thought that what was possible in, say, Northern Italy, was different from what was possible in Saint Petersburg. And it required, then, a different set of tactics and strategies. That is very much how I think about politics.

I have always remained very optimistic about political possibilities, and not because of some sort of delusion. I see why people get off on a complete intellectual miserabilism by reading lots of Theodor W. Adorno or more recently, say, Giorgio Agamben, but I really don't understand that. Why would your intellectual life be the description of the present stale that you inhabit? Sure, the world is awful. "Something is rotten in the state of Denmark", as Shakespeare said. It still is and always was, we know that. As he said: "The world is a prison“. Denmark is a prison, yes, so what do we do with that? I'm studiedly hopeful I guess.

HBD: Now, in your book from 2007, Infinitely Demanding, you discuss a new language of civil disobedience, or a new expression of political action, inspired by modern anarchism such as street theater, festivals, performance art and the like. As examples you have mentioned Seattle in 1999 and the following WTO anti-globalization protests, not to forget the anti-war demonstrations against the Iraq and Afghanistan wars.

You called it a form of non-violent warfare made for the purpose of trying to "work within the state against the state in a political articulation that attempts to open a space of opposition. “And then you almost prophetically write: "Perhaps it is at this intensely situational, indeed local level that the atomizing, expropriating force of neo-liberal globalization is to be met, contested and resisted. That is, resistance begins by occupying and controlling the terrain upon which one stands, where one lives, works, acts and thinks.".

This raises the question whether you would identify the Occupy Wall Street movement as such an expression?

SC: Yes is the answer. A Dutch student that I know very well and with whom I discussed my views on politics and resistance told me, that this was complete bullshit. Later on she emailed me during the Arab Spring when the process came to the Tahrir Square, and she said: „My God, you were right“. She said that it is as if I provided a 
description in the book of what was happening in Egypt. That's very flattering, but of course it's wrong.

I got to that view by a number of things. I tried to think through what was going on in the so-called anti-globalization process - whatever we should call that sequence - that comes into visibility with the Seattle process and continues into the early 2000's. I was thinking about how that might be described, and of course the first language, which really seemed to be able to describe it was in Hardt \& Negri's Empire (2000). However, I was suspicious of this language, although it's a really great book.

Also, the view came about from the frustration that I was encountering with a lot of students that I was working with around Karl Marx. There was a desire to go back to Marx. So what began around 1999-2000 at Essex was a whole series of Marx reading groups. There was a desire for something else.

Lastly, the most important shift or element in what then became the picture in Infinitely Demanding was anarchism as a way or a hook to hang these things on. I was always close to the anarchist tradition. In my first few years in New York, I got to know David Graeber ${ }^{2}$ and a whole number of students and activists surrounding him. My position began to be more refined - or actually changed to some extent.

So if Infinitely Demanding looks prophetic of what happened in e.g. Occupy, I think it is because I was attending to a whole series of elements, which were taking place on the ground. I was able to offer a kind of synthesis of them. This goes back to the anthropological question: Politics can't be just theoretical or philosophical; it has to be based in a rich ethnographic, local description of what's happening.

It's not that Occupy was a continuation of the antiglobalization process, but things sort of ended up there. And the thing about Occupy is that it looked as if it fell from the sky; that it emerged spontaneously on one sunny day on September the 17th 2011. But we had been preoccupied with the idea of occupation for years beforehand. There had been a series of occupations at the New School and in other contexts. The people that were involved in these occupations were very theoretically and strategically astute. So when Occupy happened people knew what to do.

Though it looked as a spontaneous emergence there was a long preparation. It was a process of political education and the formation of activists, and then new people emerged in the movement. However, the core idea of Occupy is very simple: it's anarchist in its tactics, and it's collectivist or maybe socialist in its aspirations.
Anarchism has been discredited politically because it was utopian, unrealistic and it wasn't as macho as the Marxists seemed to be. I think what have been shown the last few years is how stupid that view is. Anarchism is the most realistic, as it were, of political possibilities. It's about bodies in space, trying to claim, or to take back the idea of democracy in a very practical way.

A recent example of this we saw in New York in the form of Occupy Sandy, which was after the hurricane (in October 2012, ed.). It turned out that the people behind Occupy was better organized than the Red Cross and the other emergency services to bring out help.

For me anarchism is about organization, that's what the „O" around the „A“ stands for. It's a kind of organization. It is self-organization. I think that Occupy showed what capacity anarchism has for organization in a very real and practical way. Self-organization takes place in a certain distance from the state. This is the idea of interstitial distance to the state that I developed in Infinitely Demanding. It seems to be a way in which politics works.

Then the next question is: Does one just remain at that distance from the state? Does one try to put pressure on the state? Does one try to develop a political party that could become integrated in the state? Or does one aspire to the total dissolution of the state?

I think these are different political possibilities of which we can think about. I think the problem with the Arab Spring was that it in many ways corresponded to a kind of Western fantasy - a revolution - and it has been followed by massive disappointment. It was the emergence of radically democratic forces, which were overthrowing an authoritarian state structure with the power of the powerless. It was the classical scenario. But in that context, the problem was, to go back to Gramsci and what he calls, passive revolution. For Gramsci this is where it looks like a revolution but the fundamental political institutions remain the same.

So revolution is an illusion. And in many ways this is the risk of what might happen in Egypt. It had the appearance of revolution, but its institutions and the state itself have remained in place and now we are seeing a kind for reactionary formation. Now, I am happy about what have happened there, but it's only a partial actualization of the potential.

HBD: Wasn't it the kind of democratization as self-determination that you have dealt with in Infinitely Demanding?

SC: In the Arab world in particular, why should the state be the practical unit? In these countries, British and French imperialists largely created the state in the early parts of the 20th century. I see the energy that was 
unleashed in places like Tunisia, Egypt and Libya as a more complicated example, and it shouldn't exhaust itself against the goal of the state. It could lead to new forms of political possibilities, which could be more local or federal.

$H B D$ : Though we can observe various agendas and directions of "the Occupy movement", does it make sense to talk about the emergence of a new kind of critique from the left in the wake of this type of protests?

SC: I think it's a reemergence. In politics, we always find a mix of the old and the new. So, Occupy, The Arab Spring, the Seattle Protests etc., these are very old and classical political expressions of aspiration. They are aspirations of autonomy, for self-determination and against inequality in particular. The thing the Occupy movement in particular put at the center was the fact of inequality. And that's the question the Left begins with. Think about Rousseau's Discourse on Inequality (1754). These new movements are the reemergence of very classical political aspirations. What are new are the forms of mediation like social networks.

It's the reemergence of direct democracy as not just a „nice“ aspiration but also something imminently practical. That's really what it's about - along with the feeling of empowerment, that we are able to actually do things. It's old and it's new.

When the Seattle protests happened there were simultaneous protests in London and elsewhere. And protesters in Tahrir Square sent pizzas to workers in Wisconsin ${ }^{3}$. That was only possible through the Internet. So the Internet has technologically made simultaneous protests possible. But my point is that what is at stake is something very old.

HBD: In your works, you have particularly emphasized the need for not just thinking ethically, but acting out this ethical demand too. One could also call it an emphasis on action. Is there a tendency among the new thinkers of the left to disregard how we should realize the critique and ideals in practical political ways?

SC: Yes, I think this is my problem with thinkers like Slavoj Žižek, Alain Badiou and Jacques Rancière. They offer a kind of luxury critique. It makes you feel good to read, and you can feel clever. They make you realize how complex the nature of ideological fantasies is, and that's great, but practically I have huge question marks about those.

In about year 2000, I began to become convinced that the central category I was working on was the cat- egory of commitment. The concept had been sort of ridiculed by thinkers like Adorno. Nevertheless, I began to arrange seminars on commitment. That led me to a reformulation of my views of ethics: That at the core of any notion of ethics there has to be an ethical subject who is committed to a demand. A demand of which the subject approves. The particular kind of demand, which I wanted to suggest, is one that we might think about as an infinite demand.

So ethics for me is subjective commitment to an infinite demand. I became suspicious of the tendency of the Left to be dismissive of ethics as a category. There's a long tradition of that within strands of Marxism - that ethics is just bourgeois reflection or mediation. Again, anarchism is a practical tradition, a tradition of action, but it has always been much more theoretically vague than Marxism. There's a suspicion of high theory in anarchism, which I can understand although I think it's a bit misplaced.

What I think was going on at the Seattle Protests was interesting. Here was, what Gramsci would call a hegemony, a hegemonic front, where people with very different sets of interests suddenly got together in protest movements of anti-globalization. What tied them together was a kind of ethical commitment. It was really quite vague and it necessarily had to be vague. The vagueness centered on the idea of there being a wrong, an injustice. So, if we think about Occupy, the genius of Occupy was formulating certain statements like „we are the $99 \%$ " which was a way of combining people with very different sets of interests under the perceived moral injustice of a situation - a situation of inequality.

So the way in which politics can happen in a very practical way is through forms of articulation of demands. The traditional language of politics is about formulating demands, which can be met, and I think radical politics has to be about the formulation of demands that cannot be met. Sometimes even demands, which aren't demands. What was wonderful about Occupy was that the question often asked of them was "who are your leaders and what do you want?" and to both questions they answered, "well, we have no leaders, we have a horizontal structure. And we do not have one or two simple demands - we make a general call for accountability." They refused to play the game of politics. That was, I think, a very ethical way of approaching the problems.

I found a copy of K.E. Løgstrup's The Ethical Demand in an edition with an introduction by Alasdair MacIntyre, a great philosopher hero of mine. I found it interesting that somebody else had been trying to think through an idea of the demand. The demand obviously has a religious dimension for Løgstrup, which for me is also important. 
Morality is not some kind of nonreligious utilitarian calculus, but morality is something, which has to have an existential register. It has to touch that thing that religion also has to touch. That's what you need to motivate subjects. The core of religion, religare, is to bring together or associate. Politics have to acknowledge the ethical and religious dimension - in relation to which subjects can become motivated to act in certain sequences.

$H B D$ : In the beginning of 2012 you wrote an article on the Occupy Wall Street movement4. I sense, however, your article sent out a statement with a more general application. The article ended like this: "The disaffection with normal politics particularly among the young is vast and something else has taken shape, something at once exciting and frightening. We could be in the early stages of a perfect storm?" What do you mean by a perfect storm?

SC: As a general remark, I get so tired with $68^{\prime}$-leftists lecturing to people about what they should be thinking and doing. The situation is very different now and they have a lot to learn and little to contribute with. If you say the word "youth" they will say, "oh yes we had youth, that was what the 60's was all about". And it was, but it was youth in the context of war, the Vietnam War, but there was also a sense of possibility. A sense of dramatic cultural changes happening and all the rest.

The situation of the youth today, I think, is much more bleak and much harder. It's very difficult for even my generation to grasp it. What was going on in the Arab Spring was the emergence of a new form of youth. The same can be said about the Indignados in Europe and the protests in Britain over student fees. They were all ambiguous in the sense: What does it mean to be young? To be young today is to be in a situation where everything is impossible and where one is burdened with debt, which one cannot pay back. Is that politically enabling? It might be. It could easily fall into situations of extreme reactions, nationalisms, racism etc. It's a really unstable situation.

I was in Spain a couple of weeks ago and I was talking to Spanish students for whom for 20 years the Erasmus Program was a ticket to go to other places, which has now been partially suspended. So they owe money and they can't go anywhere. In that sense there's a new form or phenomenon of youth that can go in any direction.

Being English the two phenomena that currently speak to me was the student protests in London against the raising of fees in November 2010, and the so-called riots in the streets in London and elsewhere in August 2011. The former one was mainly a middle-class phenomenon, whereas the latter was a largely working-class phenomenon, but both connected with the youth. It seems to me that what need to be done is trying to connect the two. A problem with Occupy is it looks too white, too middleclass, and alienating from the perspective of being e.g. - not Afro-American, there was plenty of those involved - a Latino-worker. This is where the question of class comes back, and this is really a question of the Left today and not just for the 68-leftists.

For me the interesting thing about ' 68 was the occupation of Sorbonne and then this occupation leading to a series of strikes in car factories in France, and for a moment there was a genuine possibility for a cross class alliance - which didn't happen, though.

So my worry about Occupy is that, though it's fantastic what has happened and what is still happening, there's a risk of a kind of abstraction. This is why I'm still a Gramscian: Given that Occupy happened, the next task is then the formation of alliances, the formation of hegemonic alliances with groups. Particularly in the American context it would be around questions on organized labor. Thereby one has access to a completely different class viewpoint. Occupy has been rather unsuccessful at that level. Successful leftist movements always have to become broad-based cross-class alliances and it is at that point that they become genuinely powerful and frightening for those in power.

That might happen but there is a risk of abstraction and purity in Occupy. Then the big question, which is a shadow hanging above all this, is what the connection should be between Occupy and the representation apparatus of voting in the state.

There's a strong tradition in anarchism of being antipolitical where one just withdraw from it. This I'm skeptical about that. As I say in Infinitely Demanding: the state is a limitation of human existing. That's my quite romantic or pragmatic view.

It is given that we live in states and the state is a fact. The achievements of that state are not nothing when it comes to questions of enfranchisement and particularly of minorities getting access to the vote - of connecting movements like Occupy with „normal“ representation of politics. That would then take us to the question of whether there should be a party and a party form.

$H B D$ : This seems to be a continuous controversy for anarchist movements after the first face of relatively successful resistance?

SC: Forms of pragmatic alliance and compromises are often hugely important for these past reasons I was mentioning. We have been down this road before. If we think about the environmental or anti-nuclear movements in the 70's and 80's in places like Germany, which then led 
to the formation of the Green Party, which led to an access to power when Joschka Fischer was the foreign minister in Gerhard Schröder's government. However, it was obviously also a compromise.

So for me it becomes a question of how Occupy can become the impetus of a mass movement which means this difficult question has to be faced.

$H B D$ : In several texts you have pointed out that our time and especially the current form of liberal democracy have generated a massive political disappointment. Do we have any reason to be optimistic on behalf of democratic politics?

SC: Yes, but the disappointment with normal forms of politics has led to the situation where normal party politics in Western countries is just a joke. It's ludicrous. Party membership has dropped in the context that I know. Normal government is a kind of parody of itself, it seems to me.

I wrote a piece to the Guardian in $2011^{5}$, where I kick off from the argument you get in Zygmunt Bauman on the separation of politics and power. The premise of countries like Denmark or Britain is that the unity of politics and power is the state. And the state had power and had the power to get things done. Certain political views become effective.

Politics and power has fallen apart in a very radical way, it seems to me. Sovereignty has been outsourced to transnational institutions, these vague investors, banks and all the rest. So it seems to me that liberal democracy has been reduced to a kind of parody of democracy.

I found out that in the Netherlands, recently Gert Wilders is the longest serving member of parliament in the country. And he is in his late 40's and there is nobody senior to him. So politics consists of kids with no experience and for whom politics is a technocratic game. I wish only the worst for such.

The disappointment we feel with that unleashes other possibilities. The anti-globalization movement was about that. Demotivation at the level of the state can produce remotivation elsewhere. The remotivation that happens elsewhere is the political possibility that emerge.

Occupy is a wonderful example of that. In a sense there would not be any Occupy movement without the disappointment that followed Obama's victory. For a brief moment a sufficient number of Americans were diluted to believe that Obama was who they wanted him to be: central or leftish. When people realized that he really was none of those things, and that nothing was going to change, the disappointment with that found its expression in the Occupy movement.
For me philosophy and politics begin in disappointment, but they do not end there. Disappointment is the trigger that can lead to forms of affirmation and mobilization. People sometimes say that I'm the philosopher of disappointment. No, I'm the philosopher of affirmation and commitment. But that has to begin in disappointment. If you begin from the idea that things are wonderful, you are going to do nothing. It is only in relationship to disappointment, which produces a notion of injustice or wrong that can motivate a subject to act politically.

At this point, I don't really know what the various states of the rich EU are doing with their systems. It really perplexes me what this is about. There are genuine problems that need to be solved and they are doing nothing to help this. And they can't fix them because sovereignty has been outsourced firstly to these transnational institutions and even something as basic as currency has been outsourced, so they can do very little. It seems that Europe has created for itself a perfect storm of misery.

\section{HBD: Put this way, indeed it sounds fairly bleak...}

SC: I see no way out of it. There could be insurrections in Southern Europe. We have begun to see the strikes. It could also turn very nasty. It's really unclear. We have got a large disenfranchised population who has got really nothing to loose in countries like Greece. That situation can go in any political direction, and historically it tends to go the right. So it's a pessimistic note to end with.

\section{The Interview was conducted on the 15 th of November 2012.}

Simon Critchley is Hans Jonas Professor at the New School for Social Research, and a part-time professor of philosophy at Tilburg University in the Netherlands. His many books include The Ethics of Deconstruction (1992), Ethics-Politics-Subjectivity (1999), Infinitely Demanding (2007), The Book of Dead Philosophers (2009) and, most recently, The Faith of the Faithless (2012).

\section{Notes}

1. Critchley, S 2007, Infinitely Demanding: Ethics of Commitment, Politics of Resistance, Verso Books, London \& New York, pp. 113-123.

2. David Graeber is an American anthropologist and political (anarchist) activist. He is currently Reader in Social Anthropology at Goldsmiths, University of London. Among his publications are the historical monograph, Debt: The First 5,000 Years (2011) and The Democracy Project (2013) on the Occupy Movement.

3. Simultaneously with the Tahrir Square protests in Cairo, Egypt, protesters had occupied the State Capitol Building in Madison, Wisconsin, USA to stop a pending bill perceived to eliminate workers' right to collective bargaining. It became news when an Egyptian 
had called the local pizza place and placed an order to feed the protesters in Madison.

4. Critchley, S 2012, 'Occupy's Perfect Storm. Why do we have a general feeling of powerlessness?', Adbusters, 16/04/12, http://www. adbusters.org/magazine/101/occupy-perfect-storm.html
5. Critchley, S 2012, 'Occupy and the Arab spring will continue to revitalise political protest'. The Guardian, 22/03/12, http://www. guardian.co.uk/commentisfree/2012/mar/22/occupy-arab-springpolitical-protest. 